\title{
African penguins put researchers in a flap
}

\author{
Controlled fishing experiment raises controversy over cause \\ of birds' decline on Robben Island.
}

\section{BY MICHAEL CHERRY IN CAPE TOWN}

$\mathrm{R}$

obben Island is notorious as the site where Nelson Mandela spent 18 years in prison, but now the island's 1,200 breeding pairs of African penguins are sparking a scientific controversy. At stake is the survival of an endangered species, as well as how fisheries around the world are managed.

In 2013, there were just 22,000 breeding pairs of African penguins (Spheniscus demersus) worldwide: the population had declined by $65 \%$ since 2001. Possible causes include pollution, habitat loss and climate change, but a key suspect is fishing of anchovies and sardines, which are important prey for penguins.

To test this theory, in 2008, the now-defunct South African Department of Environmental Affairs and Tourism began an unusual experiment involving two pairs of islands: Robben and Dassen islands, off South Africa's west coast; and St Croix and Bird islands, off the country's south coast. For three years, a zone around one island in each pair was closed to fishing while the other island remained open. Then the situation was reversed. The rare controlled experiment has "important implications for fisheries worldwide in competition with vertebrate predators", including seabirds, seals and dolphins, says Johann Augustyn, secretary of the South African Deep-Sea Trawling Industry Association in Cape Town.

When fishing was restricted around St Croix and Bird, penguins had to expend less energy on foraging to feed their chicks, so they and their chicks were more likely to survive (L. Pichegru et al. Biol. Conserv. 156, 117-125; 2012). The areas surrounding those islands will soon be closed to fishing permanently. But for Robben Island, no clear pattern has emerged. Scientists at the University of Cape Town's Marine Research Institute, where most of the data from the experiment are analysed, are fiercely debating whether the alternating closures of Robben and Dassen islands should continue.

Those who want more time argue that it is hard to determine the effects of island closure on penguins, because natural variations in fish abundance can swamp the signal. Extending the closures for another three years should allow a signal - if there is one - to emerge, says Richard Sherley, an ornithologist at the institute.

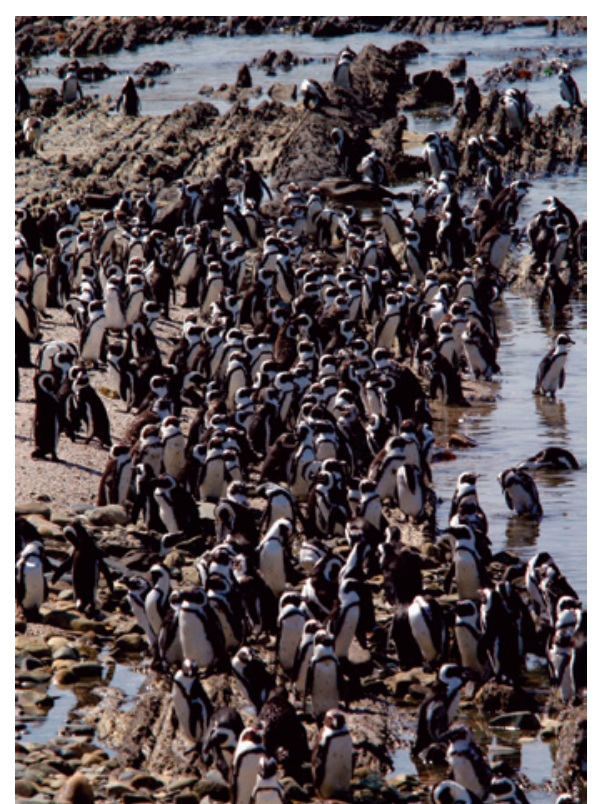

African penguins on Robben Island, South Africa.

Marine ecologist Astrid Jarre agrees that shutting the fisheries for another cycle would be a sensible precaution. The restrictions have led to small increases in chick survival, she says.

But some scientists are calling for an end to the experiment, saying that the closures damage the livelihoods of people in the fishing industry. Doug Butterworth, director of the institute's Marine Resource and Assessment Management Group, suggests that fishing may even help the penguins of Robben and Dassen islands, by breaking up shoals of anchovies and making the fish easier for penguins to catch.

Population-modelling studies of both fish and penguins by William Robinson, a former $\mathrm{PhD}$ student in Butterworth's group, flag up a problem that may be much worse for the penguins than fishing: many sardines are failing to reach maturity, and the distribution of the fish is shifting eastwards. The causes of these trends are not well understood.

A workshop in Cape Town on 13-17 October, organized by BirdLife South Africa, is evaluating the evidence from the island-closure experiment. An international panel is expected to make a recommendation to the South African Department of Agriculture, Forestry and Fisheries in the first week of December. - 